\title{
Miscelánea
}

\section{Reseña de Les dones i les professions sanitàries al llarg de la història, de Monserrat Jiménez Sureda}

\section{Review of Women and Health Professions throughout history, by Monserrat Jiménez Sureda \\ Revisão de Mulheres e profissionais de saúde ao longo da história, por Monserrat Jiménez Sureda}

\author{
Mónica Suy
}

\section{Profesora de historia e inglés en academia privada (Londres)}

Cómo citar esta reseña en edición digital: Suy, M. (2019). Reseña de "Les dones i les professions sanitàries al llarg de la història" de Monserrat Jiménez Sureda. Cultura de los Cuidados (Edición digital), 23(53). Recuperado de http://dx.doi.org/10.14198/cuid.2018.53.32

Correspondencia: Remitirse al correo electrónico

Correo electrónico: monica.suy@e-campus.uab.cat Recibido/Aceptado: Reseña invitada

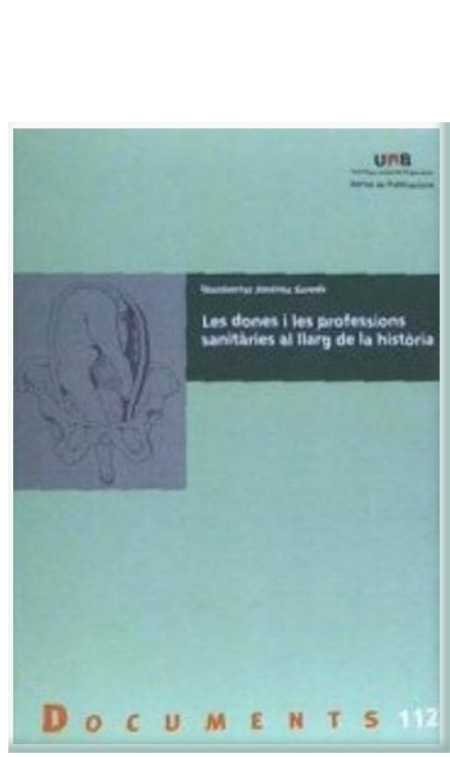

JIMÉNEZ SUREDA, Montserrat,

Les dones i les professions sanitàries al llarg de la història, Barcelona: Servei de Publicacions de la Universitat Autònoma de Barcelona, 130 pp. (PORTADA)

\section{ABSTRACT}

This review describes the essential features of the history of women in the health context. It is a very consistent book, because its historical focus is global: gender, culture, social structures, etc.

Keywords: History of Medicine, nursing history, gender and health professionals, history of women.

\section{RESUMO}

Esta revisão descreve as características essenciais da história das mulheres no contexto da saúde. É um livro muito consistente, porque seu foco histórico é global: gênero, cultura, estruturas sociais, etc. 
Palavras-chave: História da medicina, história da enfermagem, gênero e profissionais de saúde, história das mulheres.

\section{RESUMEN}

Esta reseña describe los rasgos esenciales de la historia de las mujeres en el contexto sanitario. Es un libro muy conseguido, pues su enfoque histórico es global: género, cultura, estructuras sociales, etc.

Palabras clave: Historia de la medicina, historia de la enfermería, género $\mathrm{y}$ profesionales de salud, historia de las mujeres.

Recently, I have had the pleasure of reading the latest book by Montserrat Jiménez, titled Les dones $i$ les professions sanitàries al llarg de la història. She is one of my former professors and I was delighted to have another chance at learning from her now that I do not get to see her in class. When I saw the title I thought it might be a bit confusing to me, devoted to language and literature, since its theme was apparently medicine. However, I decided to give it a try and I was gladly surprised.

From the title, one would expect it to be a complex book full of technicalities and quite dense to get through, but that is not the case at all. The book is accessible to the general public as well as to the professional readership. It is structured in short chapters where different experiences of women with medicine are illustrated and reflected on. The best thing about this structure is that all the chapters are independent from each other, telling stories from the past or present and from all parts of the world and yet, they are all related at once. Jiménez includes experiences from all social classes and races and ages. For example, in "La semiòtica de la sanació", she comments on the presence of curanderos in Mexico (and Latin America in general) but also during the European Ancien Regime and in "L'administració estatal de la sanitat pública" she exemplifies how the governments managed public health with mentions of Ancient Rome, Castille, Peru, Havana, Caracas and Naples. These are just a few instances of how diverse this book manages to be, not only within itself but also within a single chapter.

This results in the book becoming a great portrait of humanity and how all societies and cultures have struggled at some point with medicine, especially the one related with women and reproduction. It also reflects how hard women have had it throughout history in both suffering from illnesses or simply giving birth and being able to be health professionals.

Jiménez not only talks about women as health professionals but also as patients and as victims of a patriarchal society who never really allowed them to reach their full potential. The book has chapters on illnesses women have suffered from ("Les malalties femenines: clorosi, neurastènia i histèria"), the path from illiteracy to the first women becoming doctors ("Aux armes, citoyennes", "Almae matres", "D'analfabetes científiques a doctors en medicina" among others), the treatment and distrust in women from male doctors ("Medicina ars nobilissima") and even prostitution ("El mal necesario").

The author reflects on modern and alternative medicine and illustrates with examples from around the world the development of modern, more scientific medicine is taking over more traditional and alternative medicine. She mentions and reflects on homeopathy and its popularity in "El gemec poderós de la partera", "El jardí de Maria" and "El perquè de la intolerància". 
What struck me the most is just how resourceful people have managed to be with medicine throughout history. Jiménez brings light to all the work women have done in this field, which is never acknowledged and appreciated enough. Not only that but she also comments on curanderos, who historically have a bad reputation, especially now with modern medicine, but have been so important throughout history and have saved many lives. She also takes class into consideration and talks about the struggles of the lower classes of society to get treatment for illnesses and how they would often go to quacks for more traditional and cheaper but most likely worse- treatment.

Jiménez has managed to write an excellent book as a reflection on the achievements of women in the medical field as well as raising awareness of all the medical struggles from which women have suffered as patients and as victims of a heteropatriarchal society.

It is brilliant that she decides to comment on the medical situation (present and past) from other parts of the world apart from Occident. It shows that while in Occident we are advancing and women are accepted in medicine and science is more trustworthy than traditional cures, it is not the case everywhere in the world and there is still a long way to go. Some places, such as Latin America, still trust quacks quite a lot and some countries, even in Occident, still lack a public health system. It is also a way to give voice to the experiences from communities who are not as privileged as we are in Occident and raise awareness of what has been and is going on in other countries.

In conclusion, I would recommend this book to anyone who supports feminism as it makes you realize just how long women have been fighting to have a place in medicine and how long we have not been taken into account by male doctors, both as patients and as professionals. For this same reason, I think it would also be wonderful if this book was read by people who think feminism is not necessary since it proves that we have come a long way but that women are still silenced in the field. 